\title{
Antioxidant activity-guided isolation of usnic acid and diffractaic acid compounds from lichen genus Usnea sp.
}

\author{
Maulidiyah Maulidiyah ${ }^{1 *}$, Akhmad Darmawan², Erviana Ahmad', Andi Musdalifah¹, Dwiprayogo Wibowo ${ }^{3}$, \\ La Ode Agus Salim ${ }^{1}$, Zul Arham ${ }^{4}$, Faizal Mustapa ${ }^{5}$, Ishmah Farah Adiba Nurdin ${ }^{6}$, Muhammad Nurdin ${ }^{1}$ \\ ${ }^{1}$ Department of Chemistry, Faculty of Mathematics and Natural Sciences, Universitas Halu Oleo, Kendari, Indonesia. \\ ${ }^{2}$ Research Center for Chemistry, Indonesian Institute of Sciences, Banten, Indonesia. \\ ${ }^{3}$ Department of Pharmacy, Faculty of Sciences and Technology, Institut Teknologi dan Kesehatan Avicenna, Kendari, Indonesia. \\ ${ }^{4}$ Department of Mathematics and Natural Sciences, Faculty of Tarbiyah, Institut Agama Islam Negeri IAIN, Kendari, Indonesia. \\ ${ }^{5}$ Department of Aquaqulture, Faculty of Sciences and Technology, Institut Teknologi dan Kesehatan Avicenna, Kendari, Indonesia \\ ${ }^{6}$ Faculty of Medicine, Universitas Halu Oleo, Universitas Halu Oleo, Kendari, Indonesia.
}

\begin{tabular}{|c|}
\hline ARTICLE INFO \\
\hline $\begin{array}{l}\text { Received on: } 10 / 06 / 2020 \\
\text { Accepted on: } 29 / 10 / 2020 \\
\text { Available online: } 05 / 02 / 2021\end{array}$ \\
\hline $\begin{array}{l}\text { Key words: } \\
\text { Lichen, Usnea sp., usnic acid, } \\
\text { diffractaic acid, antioxidant. }\end{array}$ \\
\hline
\end{tabular}

\section{INTRODUCTION}

In recent years, the development of natural medicine has shown interesting attention to be applied to various cell generation treatments (Langer and Tirrell, 2004). It is due to the fact that there are no harmful effects on the human body and it can slowly improve cell generation. Today, the community is very concerned about maintaining a healthy and hygienic body in order to avoid viruses/bacteria and eradicate free radicals (Pompilio et al., 2013). Moreover, the coronavirus disease 2019 pandemic has increased the vigilance of people around the world to always maintain their health (Greenberg et al., 2020). Thus, it is important to maintain

\section{"Corresponding Author}

Maulidiyah Maulidiyah, Department of Chemistry, Faculty of Mathematics and Natural Sciences, Universitas Halu Oleo, Kendari, Indonesia.

E-mail:maulid06@yahoo.com a healthy body in order to avoid various diseases by utilizing natural compounds from nature. Several secondary metabolites of lichen have attracted the attention of researchers to be used as supplements to maintain the health of the human body. In addition, it is widely used in antimicrobial ointments as an antioxidant (AO) agent to destroy microbial cell membranes (Gülçin et al., 2002). The AO will also inhibit or delay the oxidation process through the initiation or propagation by oxidation reaction (free radicals) (Riley, 1994; Taghvaei and Jafari, 2015). The unique AO compounds in lichen have a very good impact on society.

Hamza Sherif and Gebreyohannes (2018) and Ajileye et al. (2015) have reported that the discovery of AO compounds can be obtained through two pathways, namely the synthesis of chemical compounds and isolation from natural ingredients. These pathways also have advantages and disadvantages to obtain $\mathrm{AO}$ ingredients; sometimes, the target compound is difficult to be isolated by considering factors including environmental, sterilization of tools and materials, and solvents (Zhai et al., 2013). In addition, 
the discovery of AO through the isolation process from natural products, such as plants and other organisms, is a more attractive choice because the synthetic AO is reported to be carcinogenetic.

Several AO compounds have been extracted by researchers from natural products, such as rosehip species (Fascella et al., 2019), Buriti (Mauritia flexuosa L.f.) (Resende et al., 2019), Agaricus bisporus (Ramos et al., 2019), bamboo (Nirmala et al., 2018), tropical fruits (Albuquerque et al., 2019), and Sida rhombifolia leaves (Ferro et al., 2019). Apart from the abovementioned sources, lichen is reported as another source of AO with high bioactivity (Ahamed et al., 2019). Lichen is an organism formed through the mutualism symbiotic between fungi and algae (cyanobacteria) (Honegger et al., 2013). It can be found in the pine forest and is very sensitive to environmental disturbances and can be used to cheaply assess air pollution (Gilbert, 1973; Neurohr Bustamante et al., 2013).

Particularly, Indonesia has a high biodiversity and has been classified as a tropical country. Based on this, various kinds of biodiversity are resistant to environmental conditions (Arifin and Nakagoshi, 2011). It also applies to lichen organisms which are strongly influenced by the environment because they are widely used as environmental indicators or bioindicators. Several studies have reported that the lichen organisms absorb chemical substances dissolved in water. If the air is very badly polluted with sulfur dioxide, there may be no lichens present (Nash, 1976). On the other hand, lichens have also been observed by researchers as AO agents such as Ramalina conduplicans (Luo et al., 2010), Ramalina terebrata (Paudel et al., 2011; Kim et al., 2018), Cladonia (Aslan et al., 2006; de Barros Alves et al., 2014; Kosanić et al., 2014a), Evernia prunastri and Pseudoevernia furfuraceae (Kosanić et al., 2013), Parmelia (Gulluce et al., 2006; Manojlović et al., 2012), and Cladonia planus (Hassan et al., 2013). The AO compounds from lichen were discovered like fumarprotocetraric (de Barros Alves et al., 2014), protocetraric acid (Tay et al., 2004), depside, dibenzofuran, dibenzoquinone (Huovinen and Ahti, 1982), Ramalin ( $\gamma$-glutamyl-N'(2-hydroxyphenyl)hydrazide) (Kim et al., 2018; Paudel et al., 2011), salazinic acid (Ingólfsdóttir et al., 1998), and atranorin (Dahlquist and Fregert, 1980; Bačkorová et al., 2011). Although they show good bioactivity as AO agents, they are also needed on various compounds test to determine their benefits for humans.

Based on our previous study, the lichen Usnea sp. contains secondary metabolite compounds such as 3-[1'-(2",3"-dihydroxyphenyl)-propyl]-7-hydroxy-chroman-4-one (Maulidiyah et al., 2018), (5E,6E) 5-ethylidene-7-formyl-6,7-hydroxy methyl hept-6enoate (Maulidiyah et al., 2016b), Eumitrin A1 (Maulidiyah et al., 2015), 2'-hydroxy-1'-(4-hydroxyl-5-methoxy-2-methyl-phenyl)etone (Maulidiyah et al., 2011), and atranorin (Maulidiyah et al., 2016a). In this study, we explore the potential of AO activity against usnic acid and diffractaic acid compounds based on the lichen genus Usnea sp., originating from Southeast Sulawesi, Indonesia. The isolation of organic compounds (usnic acid and diffractaic acid) and their AO test will be discussed in detail.

\section{EXPERIMENTAL METHOD}

\section{Extraction and purification of lichen Usnea sp.}

Isolation of secondary metabolites from lichen Usnea $\mathrm{sp}$. was conducted by considering the steps including the extraction, separation, and purification. Firstly, in the sample preparation, the lichen was collected from the pine forest in Mowewe district, Southeast Sulawesi, Indonesia. It was cleaned and dried at room temperature and then crushed into small pieces to optimize the maceration process. After that, the lichen was macerated for $3 \times 24$ hours using an acetone solvent (Merck, Germany) and filtered every 24 hours to obtain an acetone extract from the lichen. The separation step was conducted using column chromatography gravity (Pyrex) in the stationary phase with silica gel 60G $(0.063-0.200 \mathrm{~mm})$ and eluted gradient with n-hexane and ethyl acetate solvents (Merck, Germany), whereas in the purification process, it was fractionated by using Thinlayer chromatography (TLC) under the acetone extract to observe the spot stains which indicates that the compound was pure. Based on nine fractions (Fig. 1), we observe that the fractions of 5 (L5) and 7 (L7) exhibit the formation of a crystal needle and are characterized using a 1D-NMR spectrometer (JEOL JNM ECA 500).

\section{Antioxidant activity test}

The AO activity test was applied using the 2,2-diphenyl1-picrylhydrazyl (DPPH) method based on those reported by Kosanić et al. (2014b), where $2 \mathrm{ml}$ methanol and $0.05 \mathrm{mg} \cdot \mathrm{ml}^{-1}$ DPPH solutions were added into a glass cuvette and mixed with sample concentrations of $1,5,10$, and $15 \mu \mathrm{g} \cdot \mathrm{ml}^{-1}$, respectively. The solution was mixed and shaken vigorously at an ambient temperature, and then incubated for 30 minutes. Finally, it was analyzed using UV-vis spectrophotometer (UV-2550, Shimadzu, Japan) on $\lambda_{\text {max }}=515 \mathrm{~nm}$ and its AO capacity was calculated by referring to the following equation (Kosanić et al., 2014b):

$$
\% \text { Antioxidant }=\left(\mathrm{A}_{0}-\mathrm{A}_{1}\right) \mathrm{A}_{0} \times 100
$$

where $A_{0}$ is the absorbance of the negative control and $A_{1}$ is the absorbance of the reaction mixture or standard. Quercetin was used as the positive control in this treatment.

\section{RESULTS AND DISCUSSION}

\section{Identification of secondary metabolite compounds}

Isolation of secondary metabolites from lichen Usnea $\mathrm{sp}$. was successfully isolated by the isolation procedure using the TLC technique to observe a single color spot on the TLC plate showing the acquisition of pure compound (Fig. 1). It can be seen that there were nine fractions, but only two fractions show a single color spot, namely L5 and L7, with yellow and white crystals (Fig. 2). To confirm this, the secondary metabolite compound on L5 was evaluated using 1D-NMR spectroscopy $(1 \mathrm{H}$ proton and $13 \mathrm{C}$ carbon) as shown in Figure 3.

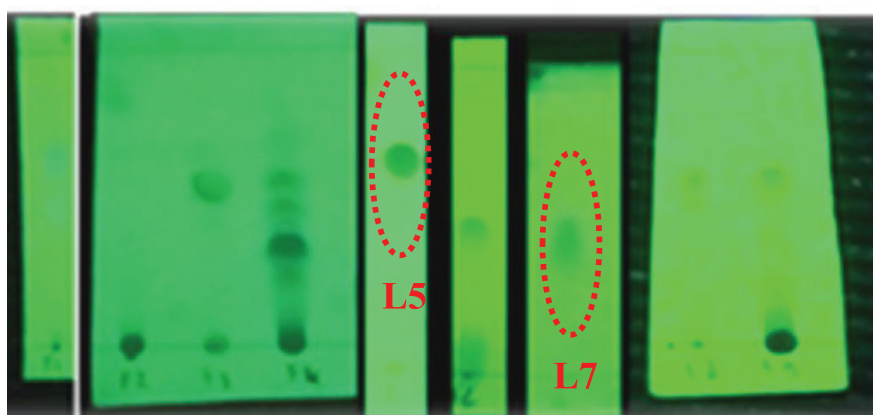

Figure 1. TLC of nine lichen Usnea fractions. 
Figure $3 \mathrm{~A}$ shows that the L5 fraction contains 18 carbon atoms in a chemical shift at 201.21, 200.97, and $191.28 \mathrm{ppm}$ which describes three carbon atoms originating from the carbonyl
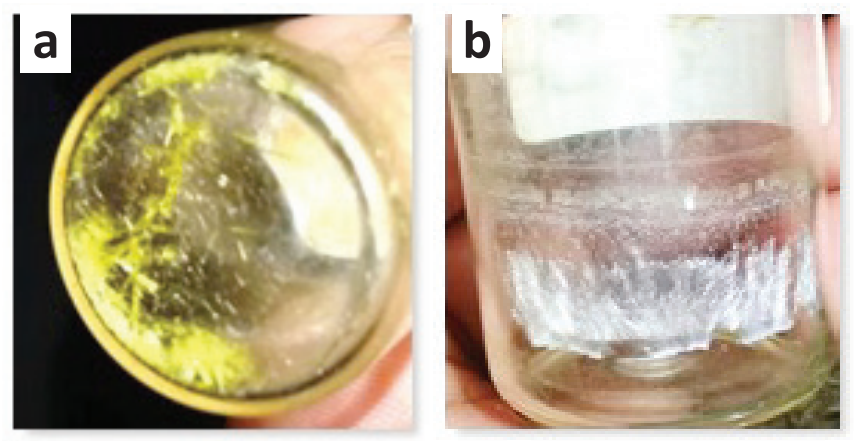

Figure 2. The formation of crystals ( $55=$ yellow; $\mathrm{L} 7=$ white $)$. group $(\mathrm{C}=\mathrm{O})$ and chemical shift at 7.57, 19.51, 27.89, 31,11, and $31,51 \mathrm{ppm}$ clarified from the methyl group $\left(\mathrm{CH}_{3}\right)$. In addition, the metin group was identified based on one carbon atom with a chemical shift at $98.36 \mathrm{ppm}$ and nine quaternary carbons with chemical shifts at $62.54,156.77,155.35,101.19,98.36,107.17$, $105.42,104.93$, and $58.61 \mathrm{ppm}$. Based on these results, there have been five carbon atoms bonded to oxygen atoms.

Moreover, the 1H-NMR (Fig. 3B) was also analyzed toward the L5 fraction, which indicates the existence of four methyl groups with chemical shifts at $0.84,1.22,1.733$, and $1.99 \mathrm{ppm}$. There are two other methyl groups that bind the $\mathrm{C}=\mathrm{O}$ group that has been identified in chemical shifts at 2.58 and 2.66 $\mathrm{ppm}$. The chemical shift at $6.30 \mathrm{ppm}$ indicates the presence of the olefinic group. In the final stage, we compare these data with the results of previous studies by Maulidiyah et al. (2011) and Huneck and Yoshimura (1996), showing that L5 has similarities with the usnic acid compound (chemical formula $\mathrm{C}_{18} \mathrm{H}_{16} \mathrm{O}_{7}$ ) (Table 1).

Table 1. Comparison of L5 isolated compound with usnic acid compounds based on the value of chemical shift of the proton and carbon.

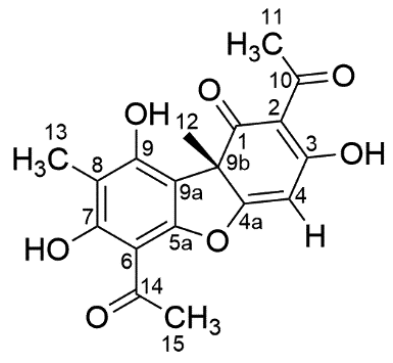

\begin{tabular}{|c|c|c|c|c|}
\hline \multirow[b]{2}{*}{ No } & \multicolumn{2}{|c|}{ Usnic acid ${ }^{a}$} & \multicolumn{2}{|c|}{ L5 Compound (1) } \\
\hline & $\begin{array}{c}{ }^{13} \mathbf{C}-\mathbf{N M R} \\
(\mathrm{ppm})\end{array}$ & $\begin{array}{c}\text { 'H-NMR } \\
(\Sigma \mathrm{H}, \text { mult., } J \text { in } \mathrm{Hz})\end{array}$ & $\begin{array}{c}{ }^{13} \mathbf{C}-\mathbf{N M R} \\
(\mathrm{ppm})\end{array}$ & $\begin{array}{c}{ }^{\mathbf{1}} \mathbf{H}-\mathbf{N M R} \\
(\Sigma \mathrm{H}, \text { mult., } J \text { in } \mathrm{Hz})\end{array}$ \\
\hline 1 & 198.06 & - & -ur- & - \\
\hline 2 & 105.24 & - & 105.42 & - \\
\hline 3 & 191.70 & - & 191.28 & - \\
\hline $3-\mathrm{OH}$ & - & $18.85(1 \mathrm{H}, s)$ & - & -ur- \\
\hline 4 & 98.31 & $5.98(1 \mathrm{H}, s)$ & 98.37 & $6.30(s)$ \\
\hline $4 a$ & 179.37 & - & 179.37 seconds & - \\
\hline $5 \mathrm{a}$ & 155.21 & - & 155.36 & - \\
\hline 6 & 101.53 & - & 101.20 & - \\
\hline 7 & 163.91 & - & 162.54 & - \\
\hline $7-\mathrm{OH}$ & - & $11.00(1 \mathrm{H}, s)$ & - & $11.33(b r-s)$ \\
\hline 8 & 109.35 & - & 107.18 & - \\
\hline 9 & 157.51 & - & 156.78 & - \\
\hline $9-\mathrm{OH}$ & - & $13.30(1 \mathrm{H}, s)$ & - & -ur- \\
\hline $9 \mathrm{a}$ & 103.94 & - & 104.94 & - \\
\hline $9 \mathrm{~b}$ & 59.08 & - & 58.62 & - \\
\hline 10 & 201.73 & - & 201.22 & - \\
\hline 11 & 32.09 & $1.76(3 \mathrm{H}, s)$ & 31.51 & $1.73(s)$ \\
\hline 12 & 27.51 & $2.67(3 \mathrm{H}, d, J=2.4 \mathrm{~Hz})$ & 27.90 & $2.67(d)$ \\
\hline 13 & 7.51 & $2.51(3 \mathrm{H}, s)$ & 7.58 & $2.50(\mathrm{~s})$ \\
\hline 14 & 200.29 & - & 200.98 & - \\
\hline 15 & 31.22 & $2.67(3 \mathrm{H}, d, J=2.4 \mathrm{~Hz})$ & 31.11 & $2.67(d)$ \\
\hline
\end{tabular}

-ur- (Unrecorded)

${ }^{a}$ Adapted from Ivanova et al. (2004) 

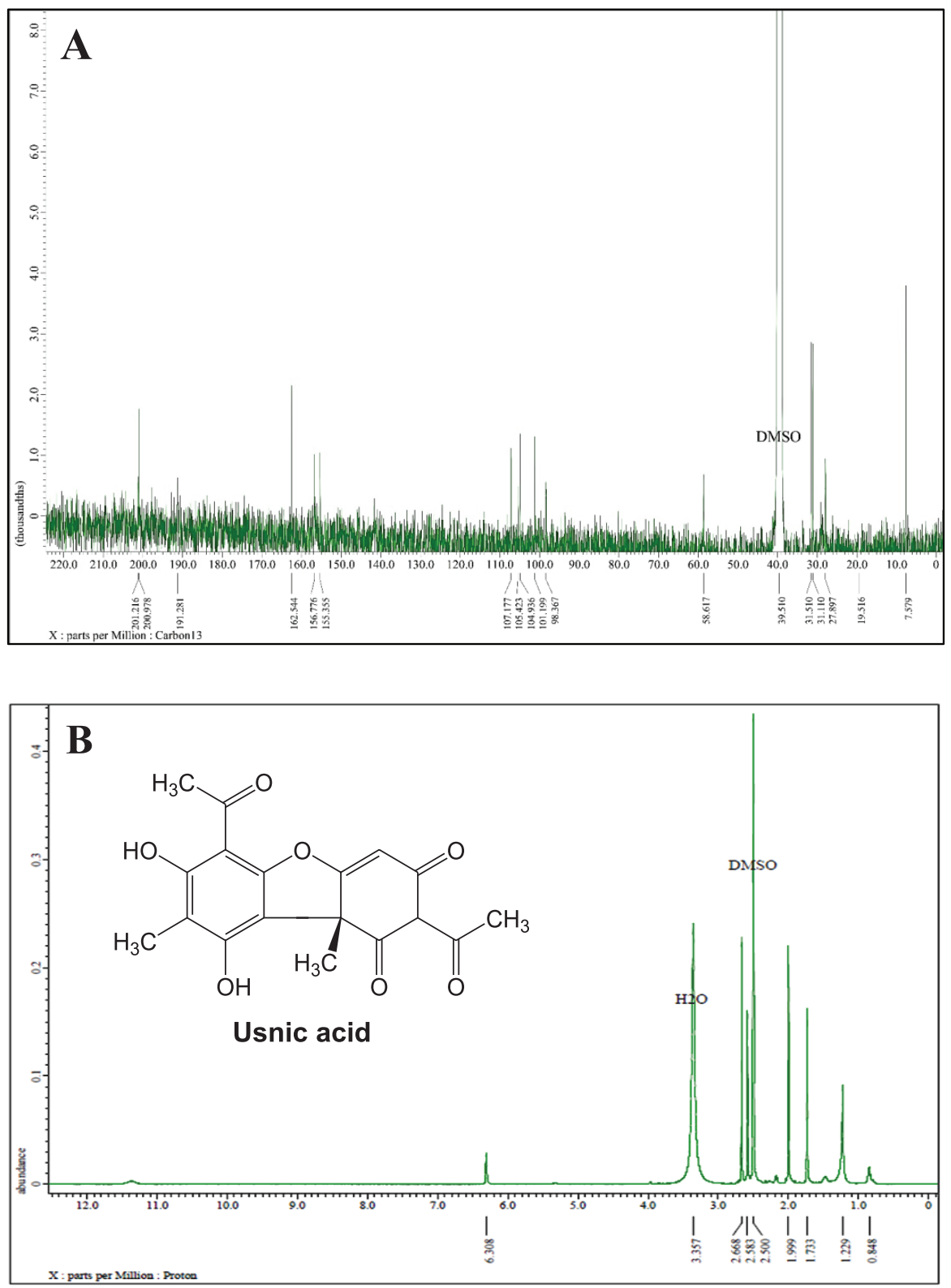

Figure 3. NMR spectra of L5 fraction compounds: (A) ${ }^{13} \mathrm{C}-\mathrm{NMR}$ spectrum and (B) ${ }^{1} \mathrm{H}-\mathrm{NMR}$ spectrum.

In the same stage, we also analyze the fraction of L7 by using 1D-NMR to identify a secondary metabolite compound in the white crystal needle. Figure 4 shows ${ }^{13} \mathrm{C}-\mathrm{NMR}$ and ${ }^{1} \mathrm{H}-\mathrm{NMR}$ data from the $\mathrm{L} 7$ fraction that presents 20 carbon atoms, wherein two carbon atoms have been bound to the carbonyl group with chemical shifts at 175.41 and 167.98 ppm. Nine quaternary carbon atoms were identified at 164.40, 161.67, 158.47, 154.38, $141.58,136.75,121.11,118.51$, and $117.77 \mathrm{ppm}$ and five of them bind directly to oxygen atoms. Moreover, two carbon atoms were expressed as methyl groups and two other carbons as methoxy groups with chemical shifts at 116.99, 109.36, 62.71, and $56.41 \mathrm{ppm}$. The presence of four carbons methyl groups was strengthened by chemical shifts at 24.13, 20.26, 9.47, and 9.19 ppm, respectively.
It was clarified based on hydrogen atoms $\left({ }^{1} \mathrm{H}\right)$ with chemical shifts at $3.79(3 \mathrm{H}, \mathrm{s}) ; 3.84(3 \mathrm{H}, \mathrm{s}) ; 2.09(3 \mathrm{H}, \mathrm{s}) ; 2.11(3 \mathrm{H}$, $\mathrm{s}) ; 2.41(3 \mathrm{H}, \mathrm{s})$; and $2.55(3 \mathrm{H}, \mathrm{s}) \mathrm{ppm}$. The other hydrogen atoms also appeared at $6.52(1 \mathrm{H}, \mathrm{s})$ and $6.66(1 \mathrm{H}, \mathrm{s}) \mathrm{ppm}$, indicating the presence of two protons; each binding to a different aromatic ring. As presented in Table 2, we conclude that the $\mathrm{L} 7$ fraction has similarities with the diffractaic acid $\left(\mathrm{C}_{20} \mathrm{H}_{22} \mathrm{O}_{7}\right)$ compound, as previously reported by Kumar and Müller (1999) and Huneck and Yoshimura (1996).

\section{Antioxidant test}

The AO activity test over acetone extract, usnic acid, and diffractaic acid compounds was conducted by the scavenging DPPH radical method. The role of AO testing was to observe the 

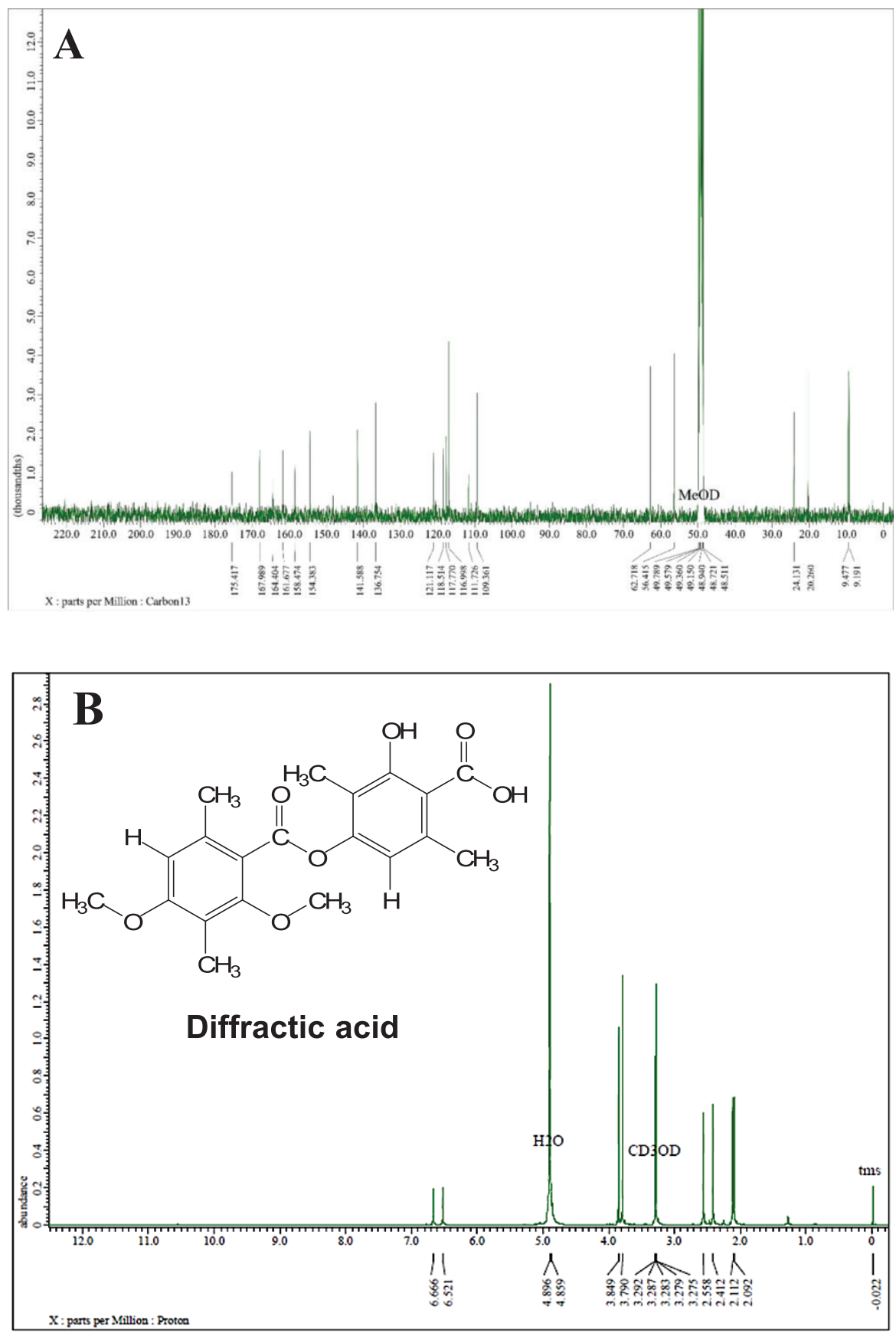

Figure 4. NMR spectra of the L7 fraction compound: (A) ${ }^{13} \mathrm{C}-\mathrm{NMR}$ spectrum and (B) ${ }^{1} \mathrm{H}-\mathrm{NMR}$ spectrum.

influencing isolated compounds with acetone extract. Hodzic and Pasalic (2009) exhibited that the AO activity test was effectively observed based on $50 \%$ inhibition concentration $\left(\mathrm{IC}_{50}\right)$ (Table 3 ). In this test, we use quercetin as a positive control to compare in AO testing of test compounds. In addition, we present the linearity equation from variation concentrations of samples (Fig. 5). The isolated lichen compounds demonstrated a higher $\mathrm{IC}_{50}$ value compared with quercetin as a positive control with an $\mathrm{IC}_{50}$ value of $5.12 \mu \mathrm{g} / \mathrm{ml}$. The lower the $\mathrm{IC}_{50}$ value of a sample, the greater the ability as an AO. Based on Table 3, it can be concluded that the high activity test is consecutive, namely quercetin, usnic acid, acetone extract, and diffractaic acid.

The scavenging of superoxide anion radicals by the tested acetone extract and compounds shows a statistically significant difference between samples and control $(p<0.05)$ (Kosanić et al., 2014b). The usnic acid showed the highest superoxide anion radical-scavenging activity compared with the acetone extract and diffractaic acid (the $\mathrm{IC}_{50}$ was $7.67 \mu \mathrm{g} \cdot \mathrm{ml}^{-1}$ ). It is due to the fact that 
Table 2. Comparison of L7 isolated compound with diffractaic acid compounds based on the value of chemical shift of the proton and carbon.<smiles>COc1cc(C)c(C(=O)Oc2cc(C)c(C(=O)O)c(O)c2C)c(OC)c1C</smiles>

\begin{tabular}{|c|c|c|c|c|}
\hline \multirow[b]{2}{*}{ No } & \multicolumn{2}{|c|}{ Diffractaic acid ${ }^{\mathrm{a}}$} & \multicolumn{2}{|c|}{ L7 Compound (1) } \\
\hline & $\begin{array}{c}{ }^{13} \mathbf{C}-\mathbf{N M R} \\
(\mathrm{ppm})\end{array}$ & $\begin{array}{c}{ }^{\mathbf{H}} \mathbf{H}-\mathbf{N M R} \\
(\Sigma \mathrm{H}, \text { mult., } J \text { in } \mathrm{Hz})\end{array}$ & $\begin{array}{c}{ }^{13} \mathbf{C}-\mathbf{N M R} \\
(\mathrm{ppm})\end{array}$ & $\begin{array}{c}\text { 'H-NMR } \\
(\Sigma \mathrm{H}, \text { mult., } J \text { in } \mathrm{Hz})\end{array}$ \\
\hline 1 & 119.73 & - & 118.51 & - \\
\hline 2 & 160.32 & - & 161.68 & - \\
\hline 3 & 117.68 & - & 117.77 & - \\
\hline 4 & 157.44 & - & 158.47 & - \\
\hline 5 & 108.38 & $6.63(1 \mathrm{H}, s)$ & 109.36 & $6.66(s)$ \\
\hline 6 & 135.76 & - & 136.75 & - \\
\hline 7 & 166.56 & - & 168.00 & - \\
\hline 8 & 9.12 & $2.17(3 \mathrm{H}, s)$ & 9.19 & $2.11(s)$ \\
\hline 9 & 20.45 & $2.48(3 \mathrm{H}, s)$ & 20.26 & $2.41(s)$ \\
\hline 1 & 117.81 & - & 116.99 & - \\
\hline 2 & 164.07 & - & 164.40 & - \\
\hline 3 & 108.71 & - & 111.73 & - \\
\hline 4 & 154.41 & - & 154.38 & - \\
\hline 5 & 116.99 & $6.63(1 \mathrm{H}, s)$ & 116.99 & $6.52(s)$ \\
\hline 6 & 141.39 & - & 141.59 & - \\
\hline $7^{\prime}$ & 176.20 & - & 175.42 & - \\
\hline $8^{\prime}$ & 9.36 & $2.19(3 \mathrm{H}, s)$ & 9.48 & $2.09(s)$ \\
\hline $9^{\prime}$ & 24.39 & $2.61(3 \mathrm{H}, s)$ & 24.13 & $2.58(s)$ \\
\hline $2-\mathrm{OCH}_{3}$ & 55.94 & $3.86(3 \mathrm{H}, s)$ & 56.42 & $3.79(s)$ \\
\hline $4-\mathrm{OCH}_{3}$ & 62.35 & $3.87(3 \mathrm{H}, s)$ & 62.72 & $3.85(s)$ \\
\hline
\end{tabular}

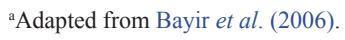

Table 3. $\mathrm{IC}_{50}$ value of the isolate compound of L5 (usnic acid) and L7 (diffractaic acid).

\begin{tabular}{lc}
\hline Test samples & $\begin{array}{c}\mathrm{IC}_{50}{ }^{a} \\
(\mu \mathrm{g} / \mathrm{ml})\end{array}$ \\
\hline Quercetin & 5.12 \\
Acetone extract & 9.42 \\
Usnic acid & 7.67 \\
Diffractaic acid & 18.51 \\
\hline
\end{tabular}

${ }^{a}$ All data were statistically significant with $p<0.05$.

usnic acid is contained over the phenolic groups (-OH) which are very reactive compounds. In fact, it was observed that the examined usnic acid containing a higher content of phenols exerted a stronger radical-scavenging effect, suggesting that phenolics are the main agents responsible for their AO activity (Kosanić et al., 2014b). Previously, the AO properties of usnic acid were also reported by Manojlović et al. (2012), wherein the usnic acid showed strong AO properties with $\mathrm{IC}_{50}$ values $p<50 \mu \mathrm{g} \cdot \mathrm{ml}^{-1}$. 

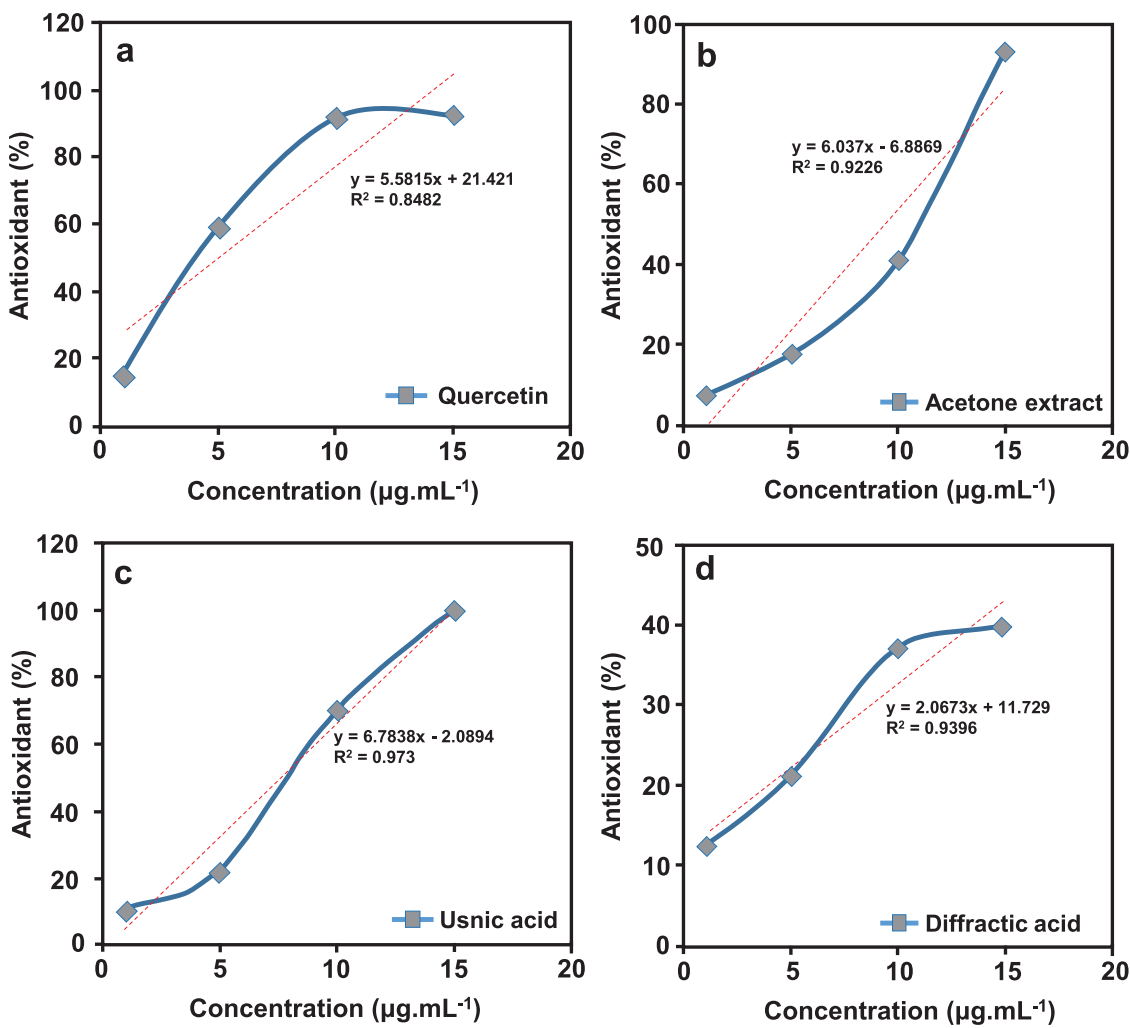

Figure 5. Linearity curve from each scavenging sample [quercetin (a), acetone extract (b), usnic acid (c), and diffractaic acid (d)].

\section{CONCLUSION}

Isolation and $\mathrm{AO}$ activity tests were successfully examined to obtain the chemical composition of acetone extract of the lichen genus Usnea sp. originally from Southeast Sulawesi, Indonesia. Based on the isolation and purification methods, the two secondary metabolites, namely usnic acid and diffractaic acid, by physical properties (color) as yellow and white crystal needles were discovered. In addition, the usnic acid compound has a strong $\mathrm{AO}$ compared to acetone extract and diffractaic acid. It is due to the fact that the strong AO activity of usnic acid is correlated with a high content of total phenols. These chemical compounds are potentially used as a natural medicinal ingredient as an $\mathrm{AO}$ agent.

\section{ACKNOWLEDGMENTS}

The authors are grateful for the financial support from the Ministry of Research and Technology/BRIN, Republic of Indonesia, under Research Grant no. 171/SP2H/AMD/LT/ DRPM/2020 and Research Center for Chemistry, Indonesian Institute of Sciences.

\section{AUTHOR CONTRIBUTIONS}

All authors made substantial contributions to conception and design, acquisition of data, or analysis and interpretation of data; took part in drafting the article or revising it critically for important intellectual content; agreed to submit to the current journal; gave final approval of the version to be published; and agree to be accountable for all aspects of the work. All the authors are eligible to be an author as per the international committee of medical journal editors (ICMJE) requirements/guidelines.

\section{CONFLICTS OF INTEREST}

The authors report no financial or any other conflicts of interest in this work.

\section{ETHICAL APPROVALS}

This study does not involve the experimentation on animal or human subjects.

\section{PUBLISHER'S NOTE}

This journal remains neutral with regard to jurisdictional claims in published institutional affiliation.

\section{REFERENCES}

Ahamed TKS, Rajan VK, Sabira K, Muraleedharan K. DFT and QTAIM based investigation on the structure and antioxidant behavior of lichen substances atranorin, evernic acid and diffractaic acid. Comput Biol Chem, 2019; 80:66-78.

Ajileye OO, Obuotor EM, Akinkunmi EO, Aderogba MA Isolation and characterization of antioxidant and antimicrobial compounds from Anacardium occidentale L.(Anacardiaceae) leaf extract. J King Saud Univ, 2015; 27:244-52.

Albuquerque MA, Levit R, Beres C, Bedani R, de Moreno MA, Isay Saad SM, Leblanc JG. Tropical fruit by-products water extracts of tropical fruit by-products as sources of soluble fibres and phenolic compounds with potential antioxidant, anti-inflammatory, and functional properties. J Funct Foods. 2019; 52:724-33.

Alves GMB, Maia MBS, Franco ES, Galvão AM, Silva TG, Gomes RM, Martins MB, Falcão EPS, Castro CMMB, Silva NH. Expectorant and antioxidant activities of purified fumarprotocetraric acid from Cladonia verticillaris lichen in mice. Pulm Pharmacol Ther, 2014; 27:139-43.

Arifin HS, Nakagoshi N. Landscape ecology and urban biodiversity in tropical Indonesian cities. Landsc Ecol Eng, 2011; 7:33-43. 
Aslan A, Güllüce M, Sökmen M, Adıgüzel A, Sahin F, Özkan H. Antioxidant and antimicrobial properties of the lichens Cladonia foliacea, Dermatocarpon miniatum, Everinia divaricata, Evernia prunastri., and Neofuscella pulla. Pharm Biol, 2006; 44:247-52.

Bačkorová M, Bačkor M, Mikeš J, Jendželovský R, Fedoročko P. Variable responses of different human cancer cells to the lichen compounds parietin, atranorin, usnic acid and gyrophoric acid. Toxicol Vitr, 2011; $25: 37-44$

Bayir Y, Odabasoglu F, Cakir A, Aslan A, Suleyman H, Halici M, Kazaz C. The inhibition of gastric mucosal lesion, oxidative stress and neutrophil-infiltration in rats by the lichen constituent diffractaic acid. Phytomedicine. 2006; 13:584-90.

Dahlquist I, Fregert S. Contact allergy to atranorin in lichens and perfumes. Contact Dermatitis, 1980; 6:111-9.

Fascella G, D’Angiolillo F, Mammano MM, Amenta M, Romeo FV, Rapisarda P, Ballistreri G. Bioactive compounds and antioxidant activity of four rose hip species from spontaneous Sicilian flora. Food Chem, 2019; 289:56-64.

Ferro DM, Mazzutti S, Vitali L, Müller CMO, Ferreira SRS Integrated extraction approach to increase the recovery of antioxidant compounds from Sida rhombifolia leaves. J Supercrit Fluids, 2019; 149:10-9.

Gilbert OL. Lichens and air pollution. In: The lichens. Elsevier, Amsterdam, Netherlands, 443-72, 1973.

Greenberg N, Docherty M, Gnanapragasam S, Wessely S. Managing mental health challenges faced by healthcare workers during covid-19 pandemic. BMJ, 2020; 368:m1211.

Gülçin İ, Oktay M, Küfrevioğlu Öİ, Aslan A. Determination of antioxidant activity of lichen Cetraria islandica (L) Ach. J Ethnopharmacol, 2002; 79:325-9.

Gulluce M, Aslan A, Sokmen MU, Sahin FI, Adiguzel A, Agar G, Sokmen AT. Screening the antioxidant and antimicrobial properties of the lichens Parmelia saxatilis, Platismatia glauca, Ramalina pollinaria, Ramalina polymorpha and Umbilicaria nylanderiana. Phytomedicine, 2006 ; $13: 515-21$

Hassan I, Keen A, Majid S, Hassan T. Evaluation of the antioxidant status in patients of lichen planus in Kashmir valley-a hospital based study. J Saudi Soc Dermatol Dermatol Surg, 2013; 17:13-6.

Hodzic Z, Pasalic H. The influence of total phenols content on antioxidant capacity in the whole grain extracts. Eur J Sci Res, 2009; $3: 471-7$.

Honegger R, Edwards D, Axe L. The earliest records of internally stratified cyanobacterial and algal lichens from the Lower Devonian of the Welsh Borderland. New Phytol, 2013; 197:264-75.

Huneck S, Yoshimura I. Identification of lichen substances. In: Identification of lichen substances. Springer, Berlin, Germany, 11-123, 1996.

Huovinen K, Ahti T. Biosequential patterns for the formation of depsides, depsidones and dibenzofurans in the genus Cladonia (lichenforming ascomycetes). Ann Botanici Fennici, 1982; 19(4): 225-34.

Ingólfsdóttir K, Chung GAC, Skúlason VG, Gissurarson SR, Vilhelmsdóttir M. Antimycobacterial activity of lichen metabolites in vitro. Eur J Pharm Sci, 1998; 6:141-4.

Ivanova V, Graefe U, Schlegel B, Kolarova M, Aleksieva K, Najdenski H, Tzvetkova I, Chipeva V. Usnic acid, metabolite from Neuropogon sp., an Antarctic lichen isolation, structure elucidation and biological activity. Biotechnol Biotechnol Equip, 2004; 18:66-71.

Kim M-K, Kim MA, Yim JH, Lee D-H, Cho SK, Yang S-G. Ramalin, an antioxidant compound derived from Antarctic lichen, prevents progression of liver fibrosis induced by dimethylnitrosamine (DNM) in rats. Biochem Biophys Res Commun, 2018; 504:25-33.

Kosanić M, Manojlović N, Janković S, Stanojković T, Ranković B. Evernia prunastri and Pseudoevernia furfuraceae lichens and their major metabolites as antioxidant, antimicrobial and anticancer agents. Food Chem Toxicol, 2013; 53:112-8.

Kosanić M, Ranković B, Stanojković T, Rančić A, Manojlović N. Cladonia lichens and their major metabolites as possible natural antioxidant, antimicrobial and anticancer agents. LWT Food Sci Technol, 2014a; 59:518-25.

Kosanić M, Ranković B, Stanojković T, Vasiljević P, Manojlović N. Biological activities and chemical composition of lichens from Serbia. EXCLI J, 2014b; 13:1226-38.

Kumar S, Müller K. Depsides as non-redox inhibitors of leukotriene $\mathrm{B} 4$ biosynthesis and $\mathrm{HaCaT}$ cell growth. 1. Novel analogues of barbatic and diffractaic acid. Eur J Med Chem, 1999; 34:1035-42.

Langer R, Tirrell DA. Designing materials for biology and medicine. Nature, 2004; 428:487-92.

Luo H, Wei X, Yamamoto Y, Liu Y, Wang L, Jung JS, Koh YJ, Hur JS. Antioxidant activities of edible lichen Ramalina conduplicans and its free radical-scavenging constituents. Mycoscience, 2010; 51:391-5.

Manojlović N, Ranković B, Kosanić M, Vasiljević P, Stanojković T. Chemical composition of three Parmelia lichens and antioxidant, antimicrobial and cytotoxic activities of some their major metabolites Phytomedicine, 2012; 19:1166-72.

Maulidiyah M, Cahyana AH, Suwarso WP. A new phenolic compound from acetone extract of lichen Usnea flexuosa Tayl. Indones J Chem, 2011; 11:290-4.

Maulidiyah I, Cahyana AH, Suwarso WP, Nurdin M. Isolation and structure elucidation of eumitrin A1 from lichen Usnea blepharea Motyka and its cytotoxic activity. Int J Pharm Tech Res, 2015; 8:782-9.

Maulidiyah M, Hasan A, Irna WO, Nurdin IFA, Kusmalawati T, Imran, Watoni AH, Azis T, Darmawan A. Antifungal potential against aspergillus flavus: secondary metabolite compound from unique organism of lichen Teloschistes Flavicans. Int Res J Pharm, 2018; 9:30-5.

Maulidiyah M, Sabarwati SH, Safutra E, Nurdin ME, Nurdin M. Atranorin secondary metabolite from lichen Usnea sp. and its antibacteria activity. Int J Pharma Bio Sci, 2016a; 7:159-69.

Maulidiyah I, Watu M, Nurdin M. Secondary metabolites identification from lichen Usnea longissima Ach.: bioactivity test of antibacterial. Int J Appl Chem, 2016b; 12:347-57.

Nash TH. Lichens as indicators of air pollution. Naturwissenschaften, 1976; 63: 364-367.

Neurohr Bustamante E, Monge-Nájera J, Méndez-Estrada VH. Use of a geographic information system and lichens to map air pollution in a tropical city: San José, Costa Rica. Rev Biol Trop, 2013; 61:557-63.

Nirmala C, Bisht MS, Bajwa HK, Santosh O. Bamboo: A rich source of natural antioxidants and its applications in the food and pharmaceutical industry. Trends food Sci Technol, 2018; 77:91-9.

Paudel B, Bhattarai HD, Koh HY, Lee SG, Han SJ, Lee HK, Oh H, Shin HW, Yim JH. Ramalin, a novel nontoxic antioxidant compound from the Antarctic lichen Ramalina terebrata. Phytomedicine, 2011; 18:1285-90.

Pompilio A, Pomponio S, Di Vincenzo V, Crocetta V, Nicoletti M, Piovano M, Garbarino JA, Di Bonaventura G. Antimicrobial and antibiofilm activity of secondary metabolites of lichens against methicillinresistant Staphylococcus aureus strains from cystic fibrosis patients. Future Microbiol, 2013; 8:281-92.

Ramos M, Burgos N, Barnard A, Evans G, Preece J, Graz M, Ruthes AC, Jiménez-Quero A, Martínez-Abad A, Vilaplana F, Ngoc LP. Agaricus bisporus and its by-products as a source of valuable extracts and bioactive compounds. Food Chem, 2019; 292:176-87.

Resende LM, Franca AS, Oliveira LS. Buriti (Mauritia flexuosa $L . \quad f$.) fruit by-products flours: evaluation as source of dietary fibers and natural antioxidants. Food Chem, 2019; 270:53-60.

Riley PA. Free radicals in biology: oxidative stress and the effects of ionizing radiation. Int J Radiat Biol, 1994; 65:27-33.

Sherif SH, Gebreyohannes B. Synthesis, characterization, and antioxidant activities of genistein, biochanin $\mathrm{A}$, and their analogues. J. Chem, 2018; 4032105: 1-6.

Taghvaei M, Jafari SM. Application and stability of natural antioxidants in edible oils in order to substitute synthetic additives. J Food Sci Technol, 2015; 52:1272-82. 
Tay T, Türk AÖ, Yılmaz M, Türk H, Kıvanç M. Evaluation of the antimicrobial activity of the acetone extract of the lichen Ramalina farinacea and its (+)-usnic acid, norstictic acid, and protocetraric acid constituents. Z Naturforsch C J Biosci, 2004; 59:384-8.

Zhai Y, Zhou K, Xue Y, Qin F, Yang L, Yao X. Synthesis of watersoluble chitosan-coated nanoceria with excellent antioxidant properties. Rsc Adv, 2013; 3:6833-8.
How to cite this article:

Maulidiyah M, Darmawan A, Ahmad E, Musdalifah A, Wibowo D, Salim LOA, Arham Z, Mustapa F, Nurdin IFA, Nurdin M. Antioxidant activity-guided isolation of usnic acid and diffractaic acid compounds from lichen genus Usnea sp. J Appl Pharm Sci, 2021; 11(02):075-083. 